Research article

\title{
Quantifying soil carbon stocks and humification through spectroscopic methods: A scoping assessment in EMBU-Kenya
}

\author{
Aline Segnini $^{\mathrm{a}, *}$, Adolfo Posadas ${ }^{\mathrm{b}}$, Wilson T.Lopes da Silva ${ }^{\mathrm{a}}$, Débora M.B.P. Milori ${ }^{\mathrm{a}}$, \\ Carla Gavilan ${ }^{\mathrm{c}}$, Lieven Claessens ${ }^{\mathrm{d}}$, Roberto Quiroz ${ }^{\mathrm{e}}$

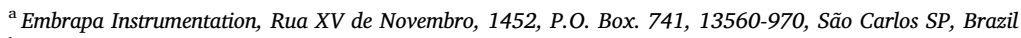 \\ ${ }^{\mathrm{b}}$ AgriEntech Ltda, Rua Oseas Rocha Ramalho, 110, CEP 13563-753, Parque Fehr, Sao Carlos, SP, Brazil \\ ${ }^{c}$ Soil and Water Science Department, University of Florida, 2181 McCarty Hall A, PO Box 110290, Gainesville, FL 32611-0290, USA \\ ${ }^{\mathrm{d}}$ International Crops Research Institute for the Semi-Arid Tropics (ICRISAT), P.O. Box 39063, 00623 Nairobi, Kenya \\ ${ }^{\mathrm{e}}$ International Potato Center (CIP), Av. La Molina, 1895, P.O. Box, 1558, Lima 12, Peru
}

\section{A R T I C L E I N F O}

\section{Keywords:}

Agricultural cropping systems

Mont Kenya

Andosols

Nitisols

Soil carbon stocks

Carbon humification

Spectroscopy

\begin{abstract}
A B S T R A C T
A soil carbon assessment was performed comparing agricultural cropping systems with natural vegetation along a sampling transect spanning different agro-ecologies on the eastern foot slopes of Mount Kenya in Embu county, $125 \mathrm{~km}$ from Nairobi, Kenya. The aim was to determine differences in soil carbon stocks and carbon recalcitrance and relate these to soil textural class, altitude, climatic parameters and land use. Soils from main agricultural systems as tea, coffee and maize-based intercropping, as well as from natural vegetation cover were sampled in triplicates, in five layers from 0 to $30 \mathrm{~cm}$ in depth and processed for total carbon analysis. The whole soil samples were also analysed using Laser-Induced Fluorescence Spectroscopy (LIFS) to assess carbon humification. Prototype portable equipment intended for future in situ analysis was used in the lab to ascertain the structure of the most recalcitrant and stable carbon present in different agro-ecosystems. In addition, Near Infrared Spectroscopy (NIRS) was tested for the quantitative analysis of soil carbon, showing that it is a reproducible and low-cost method that provided satisfactory results under the processing conditions of the samples. Results showed wide variation in the level and quality of carbon stored in the soils, depending on soil texture, land use, elevation, climate, agricultural practices and land use history. Considering the heterogeneous nature of sampled soils and the performance of NIRS and LIFS, these results can be used as a basis for the development of fully portable systems able to provide rapid, clean and potentially cost-effective relevant information for soil management.
\end{abstract}

\section{Introduction}

The global carbon cycle, soil organic carbon (SOC) sequestration, and the role of different World biomes as potential sources and sinks of carbon are receiving increasing attention (Feller and Bernoux, 2008) as carbon sequestration in plant and soil systems offers an opportunity for mitigating the greenhouse effect (Lal, 2004). This is particularly important as carbon dioxide $\left(\mathrm{CO}_{2}\right)$ levels in the atmosphere contribute to climate change. Notwithstanding, emphasis has been placed on measurements of carbon fixation by forests or measurements of carbon emissions following land-use changes (Guo and Gifford, 2002; Ontl and Schulte, 2012).

Sub-Saharan Africa is one of the poorest regions on Earth (Gilbert,
2012), with $62 \%$ of its rural population depending on agriculture as the main source of income (UNFPA, 2007; Henry et al., 2011). Agriculture also represents one of the major land use systems, thus there is a close relationship between the allocation of land for agriculture and soil carbon capture and emissions. While Africa contributes less than $4 \%$ to the global balance of $\mathrm{CO}_{2}$ emissions (Canadell et al., 2009), it accounts for $20 \%$ of the global net $\mathrm{CO}_{2}$ emissions from land-use, mainly from forest degradation and deforestation, and for approximately $40 \%$ of emissions from forest fires (Henry et al., 2009). Many management practices can increase soil carbon stocks as well as above-ground carbon in biomass, including soil conservation practices (e.g., no-tillage, reduced tillage, terracing), incorporation of crop residues, increases in cropping intensity and fertilization, and conversion of cropland to

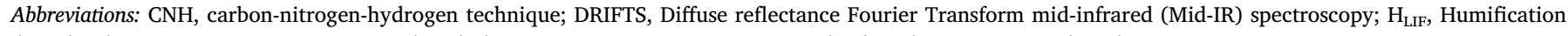
index of soil organic matter; LIFS, Laser-Induced Fluorescence Spectroscopy; MIR, mid-infrared; NIRS, Near Infrared Spectroscopy

* Corresponding author.

E-mail address: alinesegnini@hotmail.com (A. Segnini).
} 
permanent grasslands or forests (Guo and Gifford, 2002; Lal, 2004; Du Preez et al., 2011; Twongyirwe et al., 2013; Amanuel et al., 2018).

The determination of soil carbon stocks in native areas such as forests, savannas and the assessment of the impacts caused by land use changes - including conversion of these areas to smallholding agriculture - is an active research subject worldwide (Murty et al., 2002; Thangata and Hildebrand, 2012).

The chemical nature of the recalcitrant or more stable fractions of soil carbon has been assessed as an indicator of soil organic matter (SOM) quality (Canellas et al., 2007). Spectroscopic techniques are probably the best option for the analyses of whole soils, physical soil fractions and humic substances. Laser-Induced Fluorescence Spectroscopy (LIFS) analyzes recalcitrance of SOM by measuring rigid condensed aromatic structures and the magnitude of its molecular recalcitrance, which can be extremely useful in studies on carbon sequestration by soils and mitigation of $\mathrm{CO}_{2}$ emissions (Milori et al., 2011).

Near Infrared Spectroscopy (NIRS) has shown promising results for carbon quantification. Near infrared radiation $(780-2500 \mathrm{~nm})$ interacts with a soil sample, generating vibrational states in the chemical structures, detecting overtones and combinations of fundamental vibrations (Martin-Neto et al., 2009; Milori et al., 2011). This spectral region contains useful information on organic and inorganic materials in the soil. Soil organic matter can also have broad absorption bands in the visible region that are dominated by chromophores and the darkness of organic matter. Absorptions in the NIR region $(780-2500 \mathrm{~nm})$ result from the overtones of hydroxyl $(\mathrm{OH})$, sulfate $\left(\mathrm{SO}_{4}\right)$ and carbonate $\left(\mathrm{CO}_{3}\right)$ groups, as well as combinations of fundamental features of $\mathrm{H}_{2} \mathrm{O}$ and $\mathrm{CO}_{2}$ (Stenberg et al., 2010). Although near infrared is not useful for chemical structure analysis, the detection of much simpler overtones that heavily overlap to give a characteristic broad absorption band, facilitates the use of NIRS for soil analyses (Milori et al., 2011; Shepherd and Walsh, 2007). Applications of this technique to estimate soil carbon contents indicate that NIRS is a reproducible and low-cost method for quantitative analysis with high potential for field application (Madari et al., 2006; Milori et al., 2011; Shepherd and Walsh, 2007; Dinakaran et al., 2016), including the use of portable visibleNIRS equipment (Shepherd and Walsh, 2007; Li et al., 2015). In addition, NIRS has the potential to be a suitable method for soil organic carbon (Li et al., 2015) mapping for monitoring carbon sequestration (Martin et al., 2002; Kusumo et al., 2018).

Soil carbon stocks and soil carbon humification data are required for monitoring sustainable land use in intensively cropped areas. Also, the assessment and comparison of different analytical techniques is necessary in order to further develop fully portable equipment that could be used for large in situ carbon determinations. Thus, the aim of the present study was to: a) assess soil carbon stocks along a sampling transect spanning different agro-ecologies on the eastern foot slopes of Mount Kenya; b) estimate the humification of the SOM as quality indicator using LIFS; c) quantify soil carbon using NIRS instrumentation in order to evaluate a soil quantification technique and d) determine differences in soil carbon stocks and SOM recalcitrance and relate these to soil textural class, altitude, climatic parameters and land use. Our hypothesis was that the spectroscopic instruments in soil analyses could be able to improve and enlarge soil carbon assessments. This is due to the spectroscopic instruments which have portability features and low-cost advantages, LIFS and NIRS, and could be used as well in association to soil carbon sequestration studies in research fields.

\section{Materials and methods}

\subsection{Study area}

The study area was located in Embu county in the Kenyan highlands (Fig. 1). Embu is situated on the eastern footslopes of Mount Kenya (5199 m), with altitudes ranging from $1080 \mathrm{~m}$ to over $4700 \mathrm{~m}$ above sea level. The area of the county is around $700 \mathrm{~km}^{2}$. About two thirds of this area is agricultural land and one third, mainly on the higher elevations, is covered by forest. The climate is controlled by the inter-tropical convergence zone. The mean annual temperature is $25^{\circ} \mathrm{C}$ and is strongly related to elevation. It decreases from about $17^{\circ} \mathrm{C}$ in Nairobi in the central highlands. The average annual rainfall rages from 1000 to $2500 \mathrm{~mm}$ in humid areas in the central highlands (Batjes, 2004). Embu has a bimodal rainfall pattern, with the first cropping season from March to June and the second one from October to December. The maximum monthly precipitation is $300 \mathrm{~mm}$, in April. The different soils across the district are associated to the variations in rainfall, temperature and geology. Andosols, ando-humic nitisols and humic nitisols predominate in the upper midland and higher zones. These soils are of volcanic origin. Lower on the slopes, in the lower midland zones, soils based on metamorphic basement rocks with volcanic influence (Veldkamp and Visser, 1992; Jaetzold et al., 2007) that show moderate to low fertility levels are prevalent. Cambisols and Luvisols are types of soils for lower on the slopes.

\subsection{Farming systems}

Smallholder farms dominate the landscape and characterize most of the current land use. Most of cultivated land in the area is rain-fed, although in some areas farmers have access to small-scale irrigation. The average farm size is 1.2 ha with an average household size of 5 members (Munyua et al., 2010). Mixed farms predominate, with a variety of staple crops and livestock. Maize and beans are the main staple crops of the region. Banana and coffee are the cash crops in lowlands and slopes whereas tea is produced in higher grounds. Vegetables and macadamia nuts have been recently added as cash crops (Lekasi et al., 2001). Additionally, farmers grow potatoes (highlands), sweet potatoes, cassava, kale, tomato and other vegetables in places where irrigation is available. Most farmers manage a highly diversified farming system with more than 30 different crops (Olson, 2004).

In addition to crops, about $95 \%$ of Embu farmers have livestock (Mutsotso and Chirchir, 2005). A typical farm has one dairy cow, some goats and chickens. The livestock is usually held in a zero-grazing system. Napier grass (Pennisetum purpureum) is the main feed for the cows, goats and sheep, but also banana leaves and stems, maize stover, sweet potato vines, Calliandra (Calliandra calothyrsus) and other green leaves that are available (e.g. weeds from the farm and tree leaves) are used as feedstuffs. Trees are another important component of farming systems. They are usually planted along fields and farms boundaries. Common fruit and nut trees found on the farms include mango, avocado, macadamia and papaya. There are also a large variety of local trees, which are used for firewood, timber, fodder, live fences, as mulch material or for construction.

\subsection{Soil sampling transect}

The soil sampling transect was located on the Southeastern slopes of Mount Kenya. It included the major agro-ecologies of the county and was divided into three agricultural areas (Figs. 1 and 2). The first one included tea, coffee with eucalyptus and coffee plantations. The second area presented a rotation of annual crops such as maize, peas, green gram (a.k.a mung bean, Vigna radiata), and cowpeas. The third area featured maize, beans, mango, banana, cassava, papaya, peas, and green gram. In all three areas, soils under native vegetation, labeled as undisturbed soils, were sampled as a reference and their results compared against cultivated soils. In the first area, samples were taken from forested areas; whereas in the second and third areas, soils under natural vegetation (transition between forest and savanna) and crops provided the samples. 


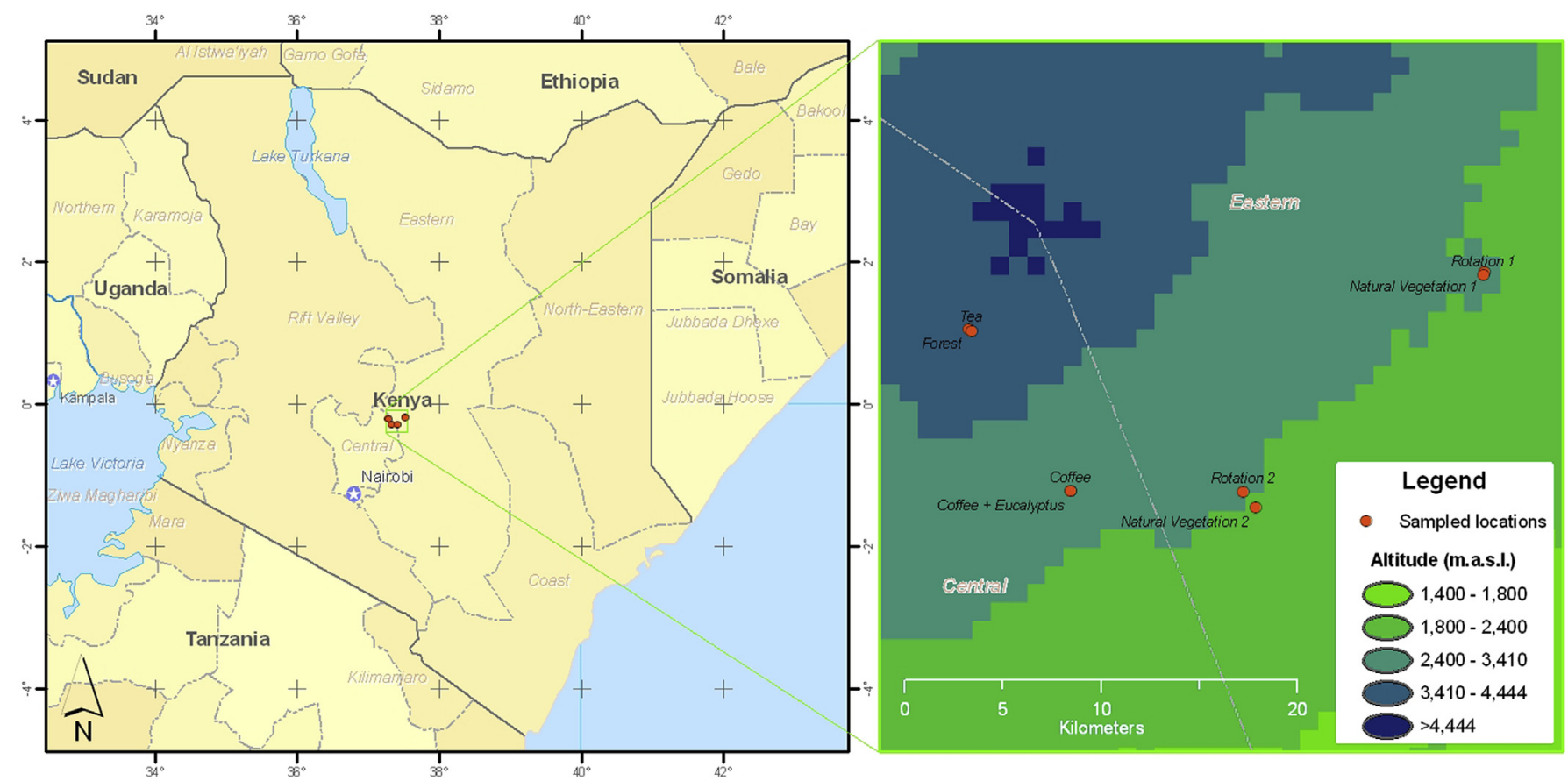

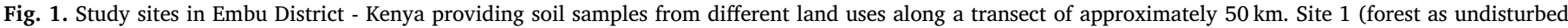

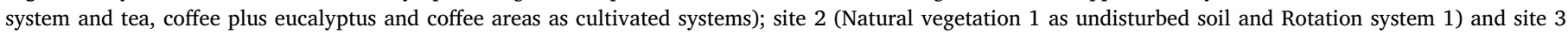
(Natural vegetation 2 and rotation system 2).

\subsection{Soil sampling and carbon stocks determination}

Soil samples were collected in April 2010 at depths: 0-2.5, 2.5-5, $5-10,10-20$ and $20-30 \mathrm{~cm}$ in three field replicates. Pits were also excavated to evaluate bulk densities in each soil layer. Samples from each depth interval were collected through an aluminum ring of known volume $\left(\sim 100 \mathrm{~cm}^{3}\right)$ and pooled for the subsequent evaluation of soil dry $\left(105^{\circ} \mathrm{C}\right)$ weight. All samples were taken on private land and no specific permissions were required. The field studies did not involve endangered or protected species.

Soil samples were air-dried and gently crushed using a mortar and pestle and passed through a $2 \mathrm{~mm}$ sieve ( 9 mesh). After this pre-treatment in Kenya, portions of soils $(5 \mathrm{~g}$ ) were transported to the Soils Laboratory at Embrapa Instrumentation in São Carlos, São Paulo, Brazil. These sub-samples were finely ground to pass through a $0.25 \mathrm{~mm}$ sieve (60 mesh) for analyses.

Total carbon analysis was performed in the Soils Laboratory, in duplicate, on approximately $10 \mathrm{mg}$ of soil samples using a 2400 CHNS/ $\mathrm{O}$ analyzer series II (Perkin-Elmer). As the quantity of inorganic carbon in the soil is relatively small or either zero per cent across the soil sampling parts from Kenyan area and soil types (Batjes, 2004), we considered that the total amount of carbon is related to organic carbon, with insignificant number of carbonates.

Soil carbon stocks are usually estimated using the soil bulk density at each depth interval and the corresponding carbon content (Veldkamp, 1994):

$\mathrm{C}$ stock $=$ soil $\mathrm{C}$ content $\times \mathrm{BD} \times$ layer depth $\times 10$

where $\mathrm{C}$ stock $\left(\mathrm{Mg} \mathrm{ha}^{-1}\right)$; $\mathrm{BD}=$ bulk density $\left(\mathrm{Mg} \mathrm{m}^{-3}\right)$ and sampled soil layer depth or thickness $(\mathrm{m})$. Soil carbon stocks by soil layer (0-2.5, $2.5-5,5-10,10-20$ and $20-30 \mathrm{~cm})$ and total $(0-30 \mathrm{~cm})$ were compared across land uses.

\subsection{Soil carbon humification}

Soil pellets of approximately $0.5 \mathrm{~g}, 1 \mathrm{~cm}$ of diameter and $2 \mathrm{~mm}$ thick, were inserted into an Embrapa Instrumentation built apparatus to acquire LIFS data (Milori et al., 2006). The equipment, with portability features, employs laser-induced optical techniques. Samples were excited by a continuous wave (cw) laser at $405 \mathrm{~nm}$ blue radiation, emitted by a diode laser equipment with a power source of around $200 \mathrm{~mW}$. The experimental parameters followed Segnini et al. (2010). The ratio of the area under this fluorescence emission band and total organic carbon content $\left(\mathrm{g} \mathrm{kg}^{-1}\right)$ was defined as a humification index $\left(\mathrm{H}_{\mathrm{LIF}}\right)$ and is expressed as arbitrary units (a.u.) (Milori et al., 2006).

\subsection{Statistical analysis}

Analysis of variance (ANOVA) was applied to show statistically significant differences. It was used ANOVA with replication using a 0.05 significance level $(p<0.05)$ and chosen to check relevant effects caused by different sites and agro-ecologies regarding soil carbon stocks and soil carbon humification. Once the normality of the distribution was established, the values found for different depths and the total layer $(0-30 \mathrm{~cm})$ were compared using a Tukey test for average comparisons, and the Brown-Forsythe test for homogeneity of variance.

\subsection{Carbon quantification using Near Infrared Spectroscopy}

Near Infrared Spectroscopy analyses were carried out using a Perkin-Elmer (Spectrum 100N) spectrometer with an Attenuated Total Reflectance (ATR) accessory. Soil samples, previously ground and sieved at 60 mesh, were scanned from 10.000 to $4.000 \mathrm{~cm}^{-1}$ $(1000-2500 \mathrm{~nm})$ at a resolution of $16 \mathrm{~cm}^{-1}$ with 64 co-added scans per spectrum. Quant + software was used to obtain the quantification model based on partial least squares (PLS) (Beebe et al., 1998). About $65 \%$ of the samples $(n=120)$ were utilized to calibrate the model to quantify soil carbon with NIRS. Thirty-five percent of the data, randomly selected, was used for the validation of the methodology using the prediction tool (Predict) software. With this procedure, the carbon values estimated by the regression model were compared with values obtained by a carbon reference technique (CHN). Absolute relative errors were individually calculated from each prediction model and the limit of detection (LOD) was estimated. Calculating LOD with direct 

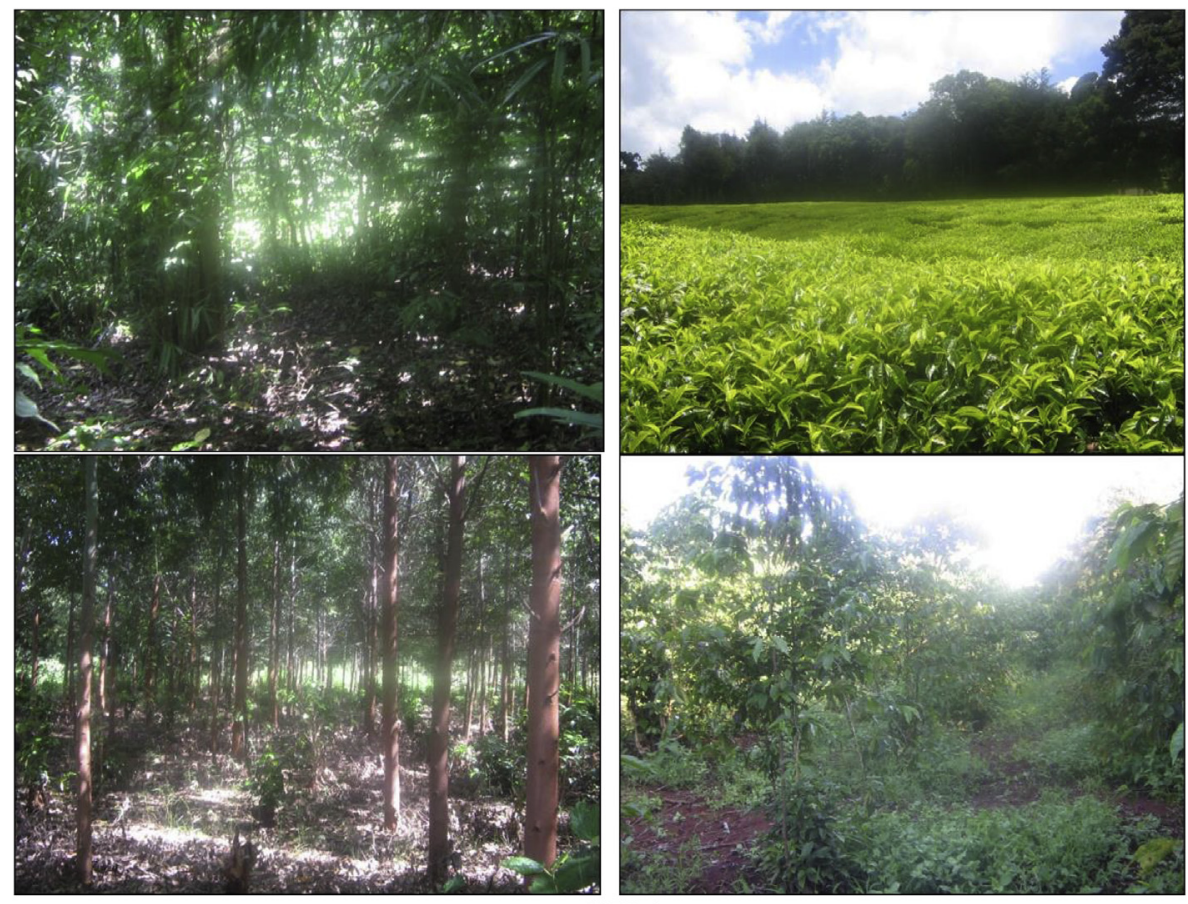

SITE 1
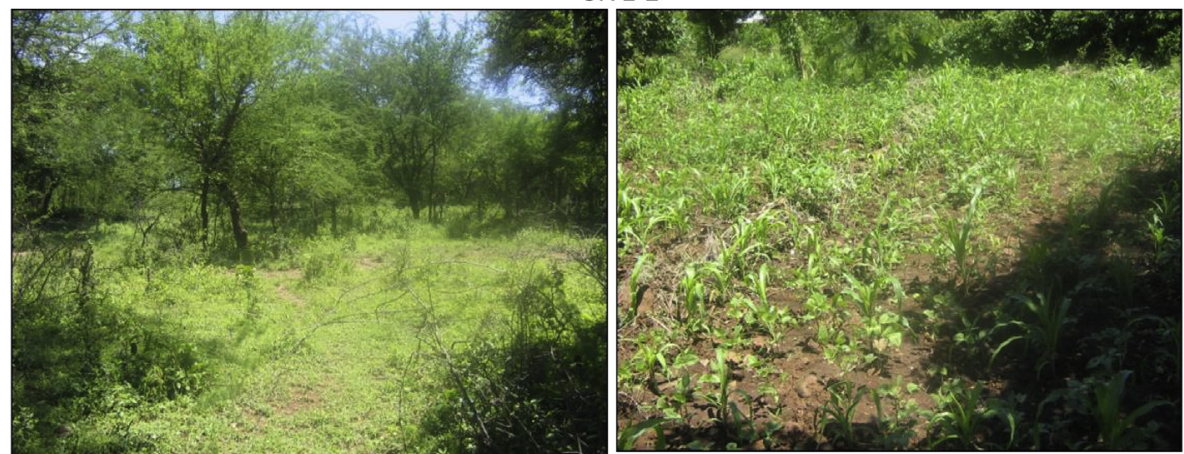

SITE 2

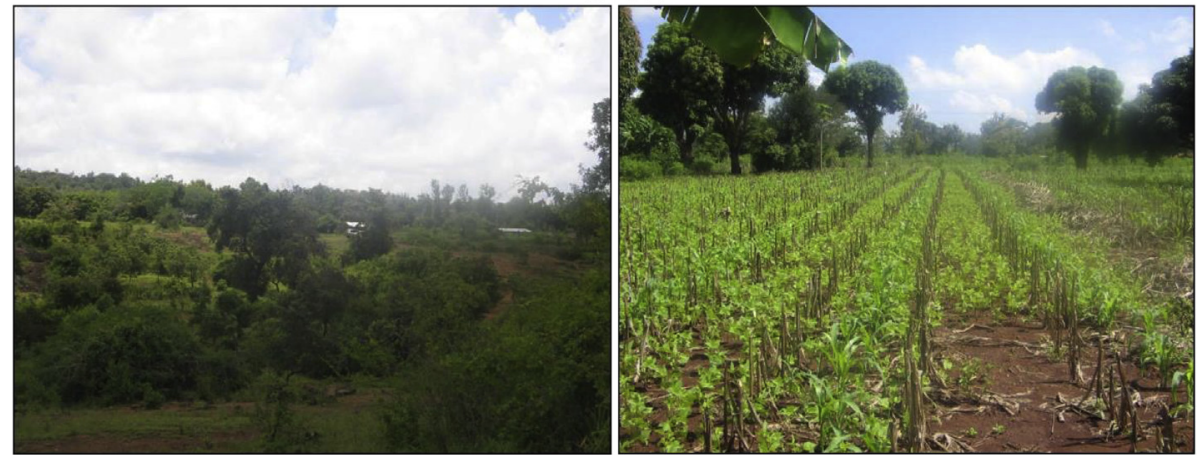

SITE 3

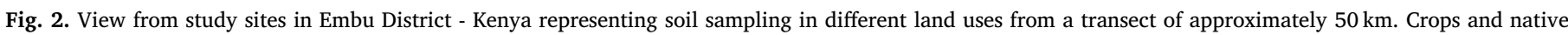

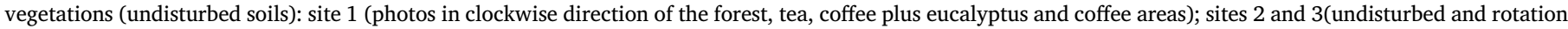
systems).

analysis of solid sample is not trivial and not standardized since the blank (sample without the analyte) is difficult to be obtained (Kurfüst, 1998; Nomura et al., 2008). Moreover, there was not a single soil sample without $\mathrm{C}$ detectable by NIRS. As an alternative, LOD was estimated following IUPAC definition ( $\mathrm{LOD}=3 \sigma / \mathrm{S}$ ), where $\sigma$ is the standard deviation of sample measurement with lower carbon concentration (an average of 10 measurements for each technique), and $S$ is the slope of the calibration curve. In addition, soil carbon values predicted by NIRS were used to calculate carbon stocks and $\mathrm{H}_{\mathrm{LIF}}$, following the methods described previously.

Standard cost-benefit analyses (including equipment cost, depreciation, maintenance, reagents use) were made to provide a reference for comparing alternative methods for quantifying soil carbon contents. 
Table 1

Soil characteristics from three study sites: 1 - forest, tea, coffee + eucalyptus and coffee; 2 - savanna and rotation system and 3 - savanna and rotation system. Mean of total sampling depth $(0-30 \mathrm{~cm})$.

\begin{tabular}{|c|c|c|c|c|c|c|c|c|}
\hline \multirow[t]{2}{*}{ sites } & \multicolumn{4}{|l|}{ Site 1} & \multicolumn{2}{|l|}{ Site 2} & \multicolumn{2}{|l|}{ Site 3} \\
\hline & Forest (undisturbed system) & Tea & Coffee + eucalyptus & Coffee & undisturbed system ${ }^{\mathrm{a}}$ & Rotation system $^{\mathrm{b}}$ & undisturbed system ${ }^{\mathrm{a}}$ & Rotation system ${ }^{c}$ \\
\hline Altitude (m) & 2012 & 2002 & 1387 & 1387 & 741 & 738 & 1198 & 1118 \\
\hline Sand (\%) & 36 & 32 & 16 & 16 & 74 & 58 & 18 & 14 \\
\hline Silt $(\%)$ & 20 & 22 & 16 & 12 & 8 & 10 & 22 & 18 \\
\hline Clay (\%) & 44 & 46 & 68 & 72 & 18 & 32 & 60 & 68 \\
\hline Soil textural class & clay & clay & clay & clay & sandy loam & sandy clay loam & clay & clay \\
\hline
\end{tabular}

a Undisturbed soil or natural vegetation: transition between forest and savanna.

b Rotation crops: maize, peas, green grams, cow peas, pumpkin.

c Rotation crops: maize, beans, mango, banana, cassava, papaya, peas, green grams.

\section{Results}

\subsection{Soil carbon stocks and humification process}

The main descriptive data of the agro-ecologies from three sites are shown in Table 1. Results for altitude and soil physical attributes are being considered. Samples were collected along a slope, with altitude values ranging from 738 to $2012 \mathrm{~m}$ above sea level. Clay soils were the dominant soil textural class, excepting site 2 , which presents sandy loam and sandy clay loam as their soil textures.

Analyses of soil carbon content and bulk densities at depth interval from different agro-ecologies are presented in Table 2. The mean bulk density ranged from $0.48( \pm 0.03) \mathrm{Mg} \mathrm{m}^{-1}$ in the $0-5-\mathrm{cm}$ depth at the tea crop (site 1) to 1.97 ( \pm 0.25$) \mathrm{Mg} \mathrm{m}^{-1}$ at rotation crops (site 2). In general, sites 2 and 3 had higher bulk densities while the mean bulk density was lower at the site 1 , mainly in the tea crop. In the study, it was noted a tendency for soil bulk densities increase with depth even in forest system (undisturbed system for site 1). Generally, this tendency is not observed in undisturbed soils, and this fact was obtained at sites 2 and 3.

Higher carbon content was obtained at forest and tea crops from site 1 (Table 2). Additionally, higher soil carbon values were obtained on the surface layers, both undisturbed soils and crops, and carbon content decreased in the lower in all systems. At the surface, forest and tea system had higher carbon amount (respectively, $10.3 \pm 0.1$ and $5.4 \pm 0.2 \mathrm{~g} \mathrm{~kg}^{-1}$ ). Another relevant information was that the rotation system for site 2 had a significant increase of carbon $\left(1.6 \pm 0.1 \mathrm{~g} \mathrm{~kg}^{-1}\right)$, comparing to undisturbed soil $\left(0.7 \pm 0.1 \mathrm{~g} \mathrm{~kg}^{-1}\right)$.

Table 3 shows the carbon stocks at the three study sites and all vegetation types. Carbon stocks were calculated in each depth and first compared by depth, for each crop, so the variation is considered by layer and in total. Considering all the layers $(0-30 \mathrm{~cm})$, the values of carbon stocks ranged to $26( \pm 3) \mathrm{Mg} \mathrm{ha}^{-1}$ for undisturbed system from site 2 to $127( \pm 9) \mathrm{Mg} \mathrm{ha}^{-1}$, for forest from site $1(p<0.05)$.

In our first sampling site, besides forest system, soil carbon stocks in cropping systems were $81( \pm 19) \mathrm{Mg} \mathrm{ha}^{-1}$ for tea, $64( \pm 4) \mathrm{Mg} \mathrm{ha}^{-1}$ for coffee plus eucalyptus and $56( \pm 4) \mathrm{Mg} \mathrm{ha}^{-1}$ for coffee. These values were all lower $(p<0.05)$ than the soils from the forest. In the second site, the reference of natural vegetation represented by a forestsavanna transition on a sandy loam soil, showed less than half the levels of $\mathrm{C}$ stocks $\left(26 \pm 3 \mathrm{Mg} \mathrm{ha}^{-1}\right)$ than soils under crops $\left(65 \pm 7 \mathrm{Mg} \mathrm{ha}^{-1}\right)$. Additionally, in the third site, the native vegetation presented higher soil carbon stocks $\left(78 \pm 4 \mathrm{Mg} \mathrm{ha}^{-1}\right.$ ) than crops under rotation $\left(51 \pm 3 \mathrm{Mg} \mathrm{ha}^{-1}\right)$. Lower $\mathrm{H}_{\text {LIFS }}$ were obtained from the surface layers of all evaluated soils (Table 4). At the surface, $\mathrm{H}_{\mathrm{LIFS}}$ was higher from the undisturbed system at site 2, and lower for forest at site $1(p \leq 0.05)$, varying accordingly to the layer depth. In the deep layers, $\mathrm{H}_{\text {LIFs }}$ presents higher values, for all systems and agro ecologies.

\subsection{Carbon quantification using NIRS}

In the present study, NIRS was used to estimate carbon contents. One outlier was detected (using the Spectrum Quant + Perkin Elmer software) and after extracting the principal components (PCs), NIRS data explained $99 \%$ of the variance in the measured data using 15 PCs. The measured values of soil C varied from $0.37 \%$ to $19.26 \%$. The carbon values, estimated by PLS multivariate regression, were compared with values obtained by a carbon reference technique (CHN). The

Table 2

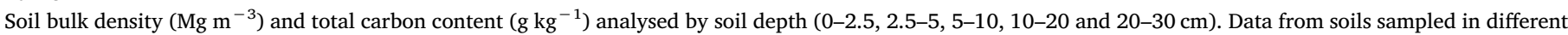
sites and cropping systems in Embu/Mbeere - Kenya. Numbers are means \pm standard deviations.

\begin{tabular}{|c|c|c|c|c|c|c|c|c|}
\hline \multirow{2}{*}{$\begin{array}{l}\text { Sites/depth } \\
(\mathrm{cm})\end{array}$} & \multicolumn{4}{|l|}{ Site 1} & \multicolumn{2}{|l|}{ Site 2} & \multicolumn{2}{|l|}{ Site 3} \\
\hline & $\begin{array}{l}\text { Forest (undisturbed } \\
\text { system) }\end{array}$ & Tea & Coffee + eucalyptus & Coffee & $\begin{array}{l}\text { undisturbed } \\
\text { system }^{\mathrm{a}}\end{array}$ & Rotation Crops ${ }^{\mathrm{b}}$ & $\begin{array}{l}\text { undisturbed } \\
\text { system }^{\text {a }}\end{array}$ & Rotation crops ${ }^{c}$ \\
\hline \multicolumn{9}{|c|}{ Bulk density $\left(\mathrm{Mg} \mathrm{m}^{-3}\right)$} \\
\hline $0-2.5$ & $0.68 \pm 0.1$ & $0.48 \pm 0.03$ & $0.86 \pm 0.10$ & $0.84 \pm 0.03$ & $1.46 \pm 0.20$ & $1.78 \pm 0.02$ & $1.01 \pm 0.12$ & $0.96 \pm 0.06$ \\
\hline $2.5-5$ & $0.68 \pm 0.1$ & $0.48 \pm 0.03$ & $0.86 \pm 0.10$ & $0.84 \pm 0.03$ & $1.46 \pm 0.23$ & $1.78 \pm 0.02$ & $1.01 \pm 0.12$ & $0.96 \pm 0.06$ \\
\hline $5-10$ & $0.76 \pm 0.05$ & $0.7 \pm 0.02$ & $0.91 \pm 0.02$ & $0.84 \pm 0.10$ & $1.52 \pm 0.20$ & $1.97 \pm 0.25$ & $1.03 \pm 0.04$ & $0.95 \pm 0.06$ \\
\hline $10-20$ & $0.79 \pm 0.05$ & $0.65 \pm 0.1$ & $0.91 \pm 0.01$ & $0.83 \pm 0.03$ & $1.54 \pm 0.09$ & $1.91 \pm 0.25$ & $1.07 \pm 0.02$ & $0.98 \pm 0.10$ \\
\hline $20-30$ & $0.83 \pm 0.10$ & $0.70 \pm 0.1$ & $0.93 \pm 0.04$ & $0.83 \pm 0.05$ & $1.53 \pm 0.10$ & $1.90 \pm 0.3$ & $0.96 \pm 0.06$ & $0.94 \pm 0.07$ \\
\hline \multicolumn{9}{|c|}{ Soil carbon content $\left(\mathrm{g} \mathrm{kg}^{-1}\right)$} \\
\hline $0-2.5$ & $10.3 \pm 0.1$ & $5.4 \pm 0.2$ & $2.8 \pm 0.1$ & $2.5 \pm 0.1$ & $0.7 \pm 0.1$ & $1.6 \pm 0.1$ & $3.8 \pm 0.1$ & $2 \pm 0.1$ \\
\hline $2.5-5$ & $7.6 \pm 0.1$ & $2.7 \pm 0.02$ & $2.6 \pm 0.1$ & $2.5 \pm 0.1$ & $0.6 \pm 0.04$ & $1.6 \pm 0.2$ & $3.3 \pm 0.1$ & $1.9 \pm 0.02$ \\
\hline $5-10$ & $6.3 \pm 0.05$ & $3.4 \pm 0.1$ & $2.9 \pm 0.1$ & $2.4 \pm 0.03$ & $0.6 \pm 0.03$ & $1.3 \pm 0.2$ & $2.8 \pm 0.1$ & $1.9 \pm 0.03$ \\
\hline $10-20$ & $5.2 \pm 0.04$ & $3.2 \pm 0.01$ & $2.3 \pm 0.02$ & $2.1 \pm 0.03$ & $0.5 \pm 0.05$ & $1.1 \pm 0.2$ & $2.6 \pm 0.1$ & $2 \pm 0.03$ \\
\hline $20-30$ & $3.8 \pm 0.05$ & $2.9 \pm 0.01$ & $2.1 \pm 0.05$ & $2.1 \pm 0.1$ & $0.5 \pm 0.03$ & $0.9 \pm 0.02$ & $1.9 \pm 0.1$ & $1.4 \pm 0.03$ \\
\hline
\end{tabular}

a Undisturbed soil or natural vegetation: transition between forest and savanna.

b Rotation crops: maize, peas, green grams, cow peas, pumpkin.

c Rotation crops: maize, beans, mango, banana, cassava, papaya, peas, green grams. 
Table 3

Soil carbon stocks $\left(\mathrm{Mg} \mathrm{ha}^{-1}\right)$ calculated by soil depth $(0-2.5,2.5-5,5-10,10-20$ and $20-30 \mathrm{~cm})$ and total layer $(0-30 \mathrm{~cm})$. Data from soils sampled in different sites and cropping systems in Embu/Mbeere - Kenya. Numbers are means \pm standard deviations.

Soil carbon stocks $\left(\mathrm{Mg} \mathrm{ha}^{-1}\right)$

\begin{tabular}{|c|c|c|c|c|c|c|c|c|}
\hline \multirow[t]{2}{*}{ Sites/depth $(\mathrm{cm})$} & \multicolumn{4}{|l|}{ Site 1} & \multicolumn{2}{|l|}{ Site 2} & \multicolumn{2}{|l|}{ Site 3} \\
\hline & $\begin{array}{l}\text { Forest (undisturbed } \\
\text { system) }\end{array}$ & Tea & Coffee + eucalyptus & Coffee & $\begin{array}{l}\text { undisturbed } \\
\text { system }^{\mathrm{a}}\end{array}$ & Rotation Crops $^{\mathrm{b}}$ & $\begin{array}{l}\text { undisturbed } \\
\text { system }^{\mathrm{a}}\end{array}$ & Rotation crops ${ }^{c}$ \\
\hline $0-2.5$ & $18 \pm 1 \mathrm{a}$ & $12 \pm 6 \mathrm{ab}$ & 6. $\pm 0.3 \mathrm{bc}$ & $5.3 \pm 0.2 \mathrm{bc}$ & $2.6 \pm 0.1 \mathrm{c}$ & $7.2 \pm 0.7 \mathrm{bc}$ & $9.7 \pm 0.1 b c$ & $4.8 \pm 0.3 \mathrm{bc}$ \\
\hline $2.5-5$ & $13 \pm 0.5 \mathrm{a}$ & $7 \pm 4 a b$ & $5.6 \pm 0.4 b$ & $5.3 \pm 0.03 b$ & $2.3 \pm 0.2 b$ & $7.1 \pm 0.6 \mathrm{~b}$ & $8.2 \pm 0.4 b$ & $4.5 \pm 0.4 b$ \\
\hline $5-10$ & $24 \pm 1 \mathrm{a}$ & $16 \pm 4 a b$ & $13 \pm 3 a b$ & $10.1 \pm 0.3 \mathrm{a}$ & $4.8 \pm 0.3 b$ & $13.1 \pm 0.6 \mathrm{ab}$ & $14.5 \pm 0.1 \mathrm{ab}$ & $9 \pm 0.4 \mathrm{ab}$ \\
\hline $10-20$ & $41 \pm 6 a$ & $26 \pm 5 a b$ & $20.5 \pm 0.4 \mathrm{bc}$ & $18 \pm 1$ & $8 \pm 0.1 c$ & $21 \pm 3 b$ & $28 \pm 2 \mathrm{ab}$ & $20 \pm 2$ bd \\
\hline $20-30$ & $31 \pm 3 a$ & $20.4 \pm 0.1 \mathrm{ab}$ & $19.1 \pm 0.5 b$ & $18 \pm 2 b$ & $8 \pm 2 c$ & $17 \pm 2 b$ & $18 \pm 1 b$ & $13.1 \pm 0.1 b$ \\
\hline Total 0-30 cm & $127 \pm 11 a$ & $81 \pm 19$ bd & $64 \pm 4 b d$ & $56 \pm 4 b$ & $26 \pm 3 c$ & $65 \pm 7$ bd & $78 \pm 4 d$ & $51 \pm 3 b$ \\
\hline
\end{tabular}

${ }^{\text {a }}$ Undisturbed soil or natural vegetation: transition between forest and savanna.

b Rotation crops: maize, peas, green grams, cow peas, pumpkin.

c Rotation crops: maize, beans, mango, banana, cassava, papaya, peas, green grams. Mean values followed in line followed by the same letter do not differ (Tukey test: $p<0.05)$.

data showed a correlation coefficient ( $r)$ of $0.99(p<0.05)$, and a mean absolute relative error to the predictions of $19.9 \%$ (Fig. 3). The LOD found for CHN and NIRS technique were, $0.11 \%$ and $0.45 \%$, respectively. The value of prediction mean error can be associated to the variation of carbon content, with a wide range of soil sampling sites. The estimated carbon values by NIRS presented more relative prediction errors for soil samples with lower carbon contents, near or lower than LOD of NIRS and CHN techniques.

Carbon stocks and humification degree using carbon values, obtained by the NIRS quantification model, were estimated. The Pearson moment correlation coefficients for the linear fit were 0.91 for carbon stocks and 0.82 for humification degree $(p<0.05)$, which compared favorably with data obtained with the reference technique for $\mathrm{C}$ determination (CHN), thus showing the high potential of NIRS for soil carbon assessment.

\section{Discussion}

\subsection{Soil carbon stocks and humification process}

The addition of soil bulk densities values to a fixed soil depth in carbon soil amount is substantial and effective to monitor soil carbon stocks. Even though bulk density is a basic parameter soil science area and the precise determination is difficult (Walter et al., 2016), the form that was used to in this paper is a standard mode (Lee et al., 2009). Also, the $0-30 \mathrm{~cm}$ depth was chosen because it is the agricultural layer, most affected by tillage (Twongyirwe et al., 2013) and has the highest soil disturbance.

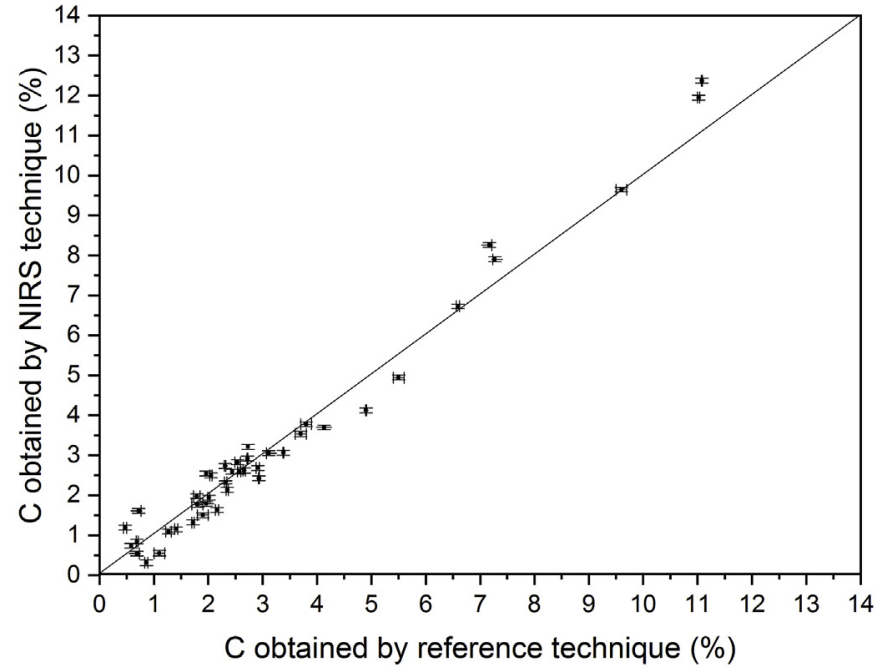

Fig. 3. Correlation between soil C predicted by NIRS and C determined by CHN $(\mathrm{R}=0.99)$.

The soil carbon amount is higher at surface layer for all agroecology systems. Superficial layers receive a continuous input of fresh material from vegetation and animals. The deposition of decayed material from roots and vegetative aerial parts on the upper layers of the soil is also the responsible to input carbon in surface layers (Segnini et al., 2019).

Table 4

Humification index of whole soils by soil layer $(0-2.5,2.5-5,5-10,10-20$ and 20-30 cm) obtained through Laser Induced Fluorescence Spectroscopy (LIFS). Data from soils sampled in different sites and cropping systems in Embu/Mbeere - Kenya. Numbers are means \pm standard deviations.

\begin{tabular}{|c|c|c|c|c|c|c|c|c|}
\hline \multicolumn{9}{|c|}{$\mathrm{H}_{\mathrm{LIF}}$ (a.u.) $\times 1000$} \\
\hline $\begin{array}{l}\text { Sites/depth } \\
(\mathrm{cm})\end{array}$ & $\begin{array}{l}\text { Forest (undisturbed } \\
\text { system) }\end{array}$ & Tea & Coffee + eucalyptus & Coffee & $\begin{array}{l}\text { undisturbed } \\
\text { system }^{\mathrm{a}}\end{array}$ & $\begin{array}{l}\text { Rotation } \\
\text { Crops }^{\mathrm{b}}\end{array}$ & undisturbed system ${ }^{\mathrm{a}}$ & Rotation crops ${ }^{c}$ \\
\hline $0-2.5$ & $6.4 \pm 0.02 \mathrm{a}$ & $13 \pm 1 \mathrm{ab}$ & $12.2 \pm 0.5 \mathrm{~b}$ & 11. $\pm 3 \mathrm{~b}$ & $62 \pm 3 \mathrm{ab}$ & $21 \pm 2 \mathrm{~d}$ & $11.1 \pm 0.7 \mathrm{c}$ & $20 \pm 3 d$ \\
\hline $2.5-5$ & $8.3 \pm 0.9 \mathrm{a}$ & $14 \pm 1 \mathrm{a}$ & $12 \pm 3 \mathrm{a}$ & $12.0 \pm 0.3 \mathrm{a}$ & $70 \pm 11 \mathrm{c}$ & $20 \pm 3$ & $11.9 \pm 0.02 \mathrm{ab}$ & $18 \pm 3 \mathrm{ad}$ \\
\hline $5-10$ & $11.4 \pm 0.3 \mathrm{a}$ & $21 \pm 2 \mathrm{a}$ & $15 \pm 1 \mathrm{ad}$ & $13 \pm 2 \mathrm{a}$ & $67 \pm 6 b$ & $25 \pm 2 c$ & $13.3 \pm 0.001 \mathrm{ad}$ & $19 \pm 3 d$ \\
\hline
\end{tabular}

${ }^{\text {a }}$ Undisturbed system or natural vegetation: transition between forest and savanna.

${ }^{b}$ Rotation crops: maize, peas, green grams, cow peas, pumpkin.

c Rotation crops: maize, beans, mango, banana, cassava, papaya, peas, green grams. Mean values followed in line followed by the same letter do not differ (Tukey test: $p<0.05$ ). 
On the other hand, the lower soil carbon concentration found in the deeper layer could be related to the reduced amount of the external inputs in to the soil (Amanuel et al., 2018). Probably, forest system and tea crops, with higher soil carbon levels at surface, have the higher input of vegetation and animals at soil surface, comparing to other systems. According to Twongyirwe et al. (2013) forest soils typically have most of their organic matter in the litter and upper soil layers. If the soil is tilled, SOM is mixed throughout the tilled soil profile which could be $30 \mathrm{~cm}$ deep. In their data with African soils from southwestern Uganda, the authors observed natural forest and major land uses (potato, tea and grazing lands) assessing the variability of carbon stocks in function of some parameters, including altitude. In our case, the altitude is not an essential parameter, mainly because the three zones are in different local sites, with different features. Our results are based on comparing undisturbed soils with land use managements.

Carbon stocks under natural forests, comparing to different land uses, for site 1, are higher and represent a large stock of carbon with a significant difference $(p<0.05)$. According to Twongyirwe et al. (2013), cultivated land and grazed lands can have more compacted soil than soil under natural forest, as our results had showed. In addition, Henry et al. (2009) reported that forests contain large aboveground carbon stocks, up to $255 \mathrm{MgC} \mathrm{ha}^{-1}$ and our data suggests that this stock is compounded by soil carbon, making forest a large carbon repository. Notwithstanding, there is a growing concern about the loss of such stocks, caused by land use changes, deforestation and forest degradation. They also pointed out that the driest tropical forests of SubSaharan Africa are particularly vulnerable to climate change. Site 3 had the same tendency that site 1 , with a decrease of carbon stocks for crop systems, compared to undisturbed soils. On the other hand, in site 2 was observed that the crop system had higher carbon stocks. According to Amanuel et al. (2018) cultivated land had lower amounts of organic carbon than other land use/land cover types, suggesting the need for sustainable cropping systems such as crop rotation, addition of organic matter, and crop residues to reverse the situation. As in our results, crop systems were compared to undisturbed or natural soils, a possible information is that the crop rotation system presented a sustainable form, with a relevant input of carbon (three times more the carbon stocks from undisturbed soil).

With respect to $\mathrm{H}_{\text {LIF }}$ - as an indicator of soil quality or recalcitrancesoils under trees and shrubs presented the largest carbon stocks but the lower humification index (Table 4), particularly at the top layers $(p<0.05)$. In general, forest soils and native vegetation from site 3 presented the lowest humification index, probably due to high input of residues. Undisturbed system from site 2 presented higher $\mathrm{H}_{\text {LIF }}$ likely associated to a very limited and slow incorporation of fresh residues, leading the microorganisms to decompose the organic matter already existing in the soil more thoroughly (González-Pérez et al., 2007).

Previous studies where LIFS was utilized to characterize soil carbon recalcitrance (Milori et al., 2006; González-Pérez et al., 2007; Segnini et al., 2011, 2013) have shown that low $\mathrm{H}_{\mathrm{LIF}}$ can be associated with the presence of labile carbon, since the constant input of plant residues overwhelms the capacity of microorganisms to metabolize them. In deeper soil layers, in most sampled soils, there was an increased $\mathrm{H}_{\mathrm{LIF}}$ associated to the presence of more aromatic recalcitrant carbon. Under these circumstances, carbon stability is deemed to be higher since the input of residues is lower, and there is further decomposition of humic substances by microorganisms (Segnini et al., 2011).

\subsection{Carbon quantification using NIRS}

These results corroborate previous findings indicating that NIRS is a good alternative for conducting soil carbon analyses, with the portability and low-cost advantages for field research in developing countries (Shepherd and Walsh, 2007; Milori et al., 2011; Ferraresi et al., 2012; Beltrame et al., 2016; Dinakaran et al., 2016; Kusumo and Sukartono, 2018). Bushong et al. (2015) assessed the accuracy for quantify SOC using NIRS, concluding that NIRS can be used as a quick and accurate method for measuring soil carbon.

Calibrations with an average $\mathrm{r}^{2}=0.98$ were obtained using DRIFTS and $r^{2}=0.96$ using NIRS for carbon concluding that for carbon calibrations both DRIFTS and NIRS can be successfully used (Madari et al., 2006). Notwithstanding, DRIFTS appears to be generally more accurate and robust. Very good calibrations were achieved for the sand and clay fractions of the soil. This study seems to confirm that soil type itself does not affect calibrations for total carbon concentrations, but the textural diversity within the sample population used for calibration influences it. The potential of NIRS to predict soil texture and mineralogy in tropical soils have been assessed by other workers (Ferraresi et al., 2012; Vendrame et al., 2012) who describe the development of the calibration models with NIRS and DRIFTS using samples from different soil textures and taxonomies. Such models indicated robustness, since the prediction of amounts of clay, silt and sand leads to a textural classification very similar to the classification obtained from the results of the classical method. These results can confirm the suitability of spectroscopic techniques for textural analysis of soils.

Beltrame et al. (2016) evaluated reference methods (dichromate oxidation and dry combustion) to provide a NIRS calibration model with higher predictive ability. A total of 161 soil samples obtained from horizons in full profiles in Brazil were used. Determination of organic carbon were accessed by PLS model based on NIR spectroscopy. The models presented feasible and acceptable results, and no significant differences in the prediction ability was observed.

Kusumo and Sukartono (2018) tested whether NIRS was able to rapidly measure carbon stock in the soil using. Soil samples collected from agricultural lands at the sub-district of Kayangan, North Lombok, Indonesia. The authors compared NIRS a conventional procedure (Walkley and Black). They considered NIRS a rapid measurement and mapping of soil carbon stock of the assessed area. Partial Least Square Regression (PLSR) was used to develop models from soil carbon data measured by conventional analysis and from spectral data scanned by NIRS $\left(R^{2}=0.756\right.$ to an average of soil carbon content of $1.03 \%$ ).

In addition, the cost-benefit analysis of the use of NIRS to determine soil carbon - considering the sample pre-preparation procedure, the equipment cost, depreciation, maintenance, reagents and analyses, and time of analysis (around $1 \mathrm{~min}$ )- was estimated to be about US\$ 0.25 per sample (considering 120,000 analyses per year as is the case in Brazil). On the other hand, the cost of CHN technique can amount to US\$ 5.10 per sample. NIRS offers advantages in terms of lower cost of equipment, maintenance and procedures, time saving, and is environmentally friendly since it does not use chemicals. These results are in agreement with Bellon-Maurel and McBratney (2011), who made a bibliographic study about techniques as NIR and MIR both used to determine soil carbon content measurements aiming at carbon credit trading.

\section{Conclusions}

Soil carbon stocks and humification were assessed using spectroscopic and conventional methods, for soils under different land uses and agro-ecologies in Embu, Kenya. The results showed wide variations in both carbon stocks and the levels of stability of carbon stored in the soil. Land use/land cover type influenced soil carbon amount in assessed soil systems, mainly in sites one and three. These variables are important for an adequate management of soils, particularly for reducing the environmental footprints of agriculture. Our results substantiated the fact that NIRS-based soil carbon assessments have an important role to play in the analysis of smallholder agriculture globally. These instruments, properly calibrated, can provide carbon content determinations and consequently enhance the feasibility of estimating soil carbon stocks at a low cost. Notwithstanding, measuring carbon stocks is not enough; an assessment of the stability of those stocks is also mandatory. The present study shows that this can be achieved with LIFS. We argue that the use of portable NIRS and LIFS can provide relevant information for soil 
management. The goal is to have repeatable measurements that can support mechanisms for promoting climate-smart agriculture and to generate schemes to compensate farmers for sound environmentally friendly agricultural practices.

\section{Acknowledgments}

We are grateful for the financial support from International Potato Center (CIP), from Peru, as well as to Brazilian Corporation for Agricultural Research - (EMBRAPA) Instrumentation from soil analyses and International Crops Research Institute for the Semi-Arid Tropics (ICRISAT), São Paulo Research Foundation (FAPESP) (Brazilian Agency) Process number 2007/58561-7 and National Council for Scientific and Technological Development (CNPq) (Brazilian Agency) Process number 158389/2011-5. This research was conducted under the Consultative Group on International Agricultural Research (CGIAR) Research Program on Water, Land and Ecosystems.

\section{References}

Amanuel, W., Yimer, F., Karltun, E., 2018. Soil organic carbon variation in relation to land use changes: the case of Birr watershed, upper Blue Nile River Basin, Ethiopia. J. Ecol. Environ. 42, 16-26.

Batjes, N.H., 2004. Soil carbon stocks and projected changes according to land use and management: a case study for Kenya. Soil Use Manag. 20, 350-356.

Beebe, K.R., Pell, R.J., Seasholtz, M.B., 1998. Chemometrics: a Pratical Guide. Wiley, New York.

Bellon-Maurel, V., McBratney, A., 2011. Near-infrared (NIR) and mid-infrared (MIR) spectroscopic techniques for assessing the amount of carbon stock in soils - critical review and research perspectives. Soil Biol. Biochem. 43, 1398-1410.

Beltrame, K.K., Souza, A.M., Coelho, M.R., Winkler, T.C.B., Souza, W.E., Valderrama, P., 2016. Soil organic carbon determination using NIRS: evaluation of dichromate oxidation and dry combustion analysis as reference methods in multivariate calibration. J. Braz. Chem. Soc. 27, 1527-1532.

Bushong, J.T., Norman, J., Slaton, N.A., 2015. Near-infrared reflectance spectroscopy as a method for determining organic carbon concentrations in soil. Commun. Soil Sci. Plant Anal. 46, 1791-1801.

Canadell, J.G., Raupach, M.R., Houghton, R.A., 2009. Anthropogenic $\mathrm{CO}_{2}$ emissions in Africa. Biogeosciences 6, 463-468.

Canellas, L.P., Baldotto, M.A., Busato, J.G., Marciano, C.R., Menezes, S.C., Silva, N.M., Rumjanek, V.M., Velloso, A.C.X., Simões, M.L., Martin-Neto, L., 2007. Stocks and quality of organic matter in an inceptisol under long-term sugarcane cultivation. Rev. Bras. Ciencia Solo 31, 331-340 (in Portuguese, with abstract in English).

Dinakaran, J., Bidalia, A., Kumar, A., Hanief, M., Meena, A., Rao, K.S., 2016. Near-infrared-Spectroscopy for determination of carbon and nitrogen in Indian soils. Commun. Soil Sci. Plant Anal. 47, 1503-1516.

Du Preez, C.C., Van Huyssteen, C.W., Mnkeni, P.N.S., 2011. Land use and soil organic matter in South Africa 1: a review on spatial variability and the influence of rangeland stock production. South Afr. J. Sci. 107 (5/6), 8.

Feller, C., Bernoux, M., 2008. Historical advances in the study of global terrestrial soil organic carbon sequestration. Waste Manag. 28, 734-740.

Ferraresi, T.M., Silva, W.T.L., Martin-Neto, L., Silveira, P.M., Madari, B.E., 2012. Infrared spectroscopy in determination of soil texture. Rev. Bras. Ciencia Solo 36, 1769-1777.

Gilbert, N., 2012. African agriculture: dirt poor. Nature 483, 525-527.

González-Pérez, M., Milori, D.M.B.P., Colnago, L.A., Martin-Neto, L., Melo, W.J., 2007. A laser-induced fluorescence spectroscopic study of organic matter in a Brazilian Oxisol under different tillage systems. Geoderma 138, 20-24.

Guo, L.B., Gifford, R.M., 2002. Soil carbon stocks and land use change: a meta analysis. Global Change Biol. 8, 345-360.

Henry, M., Valentini, R., Bernoux, M., 2009. Soil carbon stocks in ecoregions of Africa. Biogeosci. Discuss. 6, 797-823.

Henry, M., Maniatis, D., Gitz, V., Huberman, D., Valentini, R., 2011. Implementation of REDD + in sub Saharan Africa: state of knowledge, challenges and opportunities. Environ. Dev. Econ. 16, 381-404.

Jaetzold, R., Schmidt, H., Hornetz, B., Shisanya, C., 2007. Farm Management Handbook of Kenya Vol. II - Natural Conditions and Farm Management Information, second ed. Part C East Kenya Subpart C1 Eastern Province.

Kurfüst, U., 1998. Solid Sample Analysis. Springer-Verlag, Berlin-Heidelberg.

Kusumo, B.H., Sukartono, S., Busta, B., 2018. The rapid measurement of soil carbon stock using near-infrared. Technology. In: IOP Conf. Series: Earth and Environmental Science, vol 129, 012023.

Lal, R., 2004. Soil carbon sequestration to mitigate climate change. Geoderma 123, 1-22.

Lee, J., Hopmans, J.W., Rolston, D.E., Baer, S.G., Six, J., 2009. Determining soil carbon stock changes: simple bulk density corrections fail. Agric. Ecosyst. Environ. 134, 251-256.

Lekasi, J.K., Tanner, J.C., Kimani, S.K., Harris, P.J.C., 2001. Managing Manure to Sustain
Smallholder Livelihoods in the East African Highlands. DFID - Department For International Development, HDRA, Conventry, United Kingdom.

Li, S., Shi, Z., Chen, S., Ji, W., Zhou, L., Yu, W., Webster, R., 2015. In situ measurements of organic carbon in soil profiles using vis-NIR spectroscopy on the Qinghai-Tibet plateau. Environ. Sci. Technol. 49, 4980-4987.

Madari, B.E., Reeves III, J.B., Machado, P.L.O.A., Guimarães, C.M., Torres, E., McCarty, G.W., 2006. Mid- and near-infrared spectroscopic assessment of soil compositional parameters and structural indices in two Ferralsols. Geoderma 136, 245-259.

Martin, P.D., Malley, D.F., Manning, G., Fuller, L., 2002. Determination of soil organic carbon and nitrogen at the field level using near-infrared spectroscopy. Can. J. Soil Sci. 82, 413-422.

Martin-Neto, L., Milori, D.M.B.P., Silva, W.T.L., Simões, M.L., 2009. EPR, FTIR, Raman, UV-visible light absorption and fluorescence spectroscopies in studies of humic substances. In: Senesi, N., Xing, B., Huang, P.M. (Eds.), Biophysico-chemical Processes Involving Natural Organic Matter in Environmental Systems. Wiley IUPAC Series, Hoboken, New Jersey, pp. 651-728.

Milori, D.M.P.B., Galeti, H.V.A., Martin-Neto, L., Dieckow, J., González-Pérez, M., Bayer, C., Salton, J., 2006. Organic matter study of whole soil samples using laser-induced fluorescence spectroscopy. Soil Sci. Soc. Am. J. 70, 57-63.

Milori, D.M.P.B., Segnini, A., Silva, W.T.L., Posadas, A., Mares, V., Quiroz, R., MartinNeto, L., 2011. Emerging techniques for soil carbon measurements. In: Wollenberg, E., Nihart, A., Tapio-Biström, M.L., Grieg-Gran, M. (Eds.), Climate Change, Mitigation and Agriculture. CGIAR Research Program on Climate Change, Agriculture and Food Security (CCAFS). Earthscan, London, pp. 252-262.

Munyua, B., Hellin, J., Nyikal, R., Mburu, J., 2010. In: Determinants for Use of Certified Maize Seed and the Relative Importance of Transaction Costs Contributed Paper, Joint 3rd African Association of Agricultural Economists (AAAE) and 48th Agricultural Economists Association of South Africa (AEASA) Conference, Cape Town, South Africa.

Murty, D., Kirschbaum, M.U.F., Mcmurtrie, R.E., Mcgilvray, H., 2002. Does conversion of forest to agricultural land change soil carbon and nitrogen? A review of the literature Global Change Biol. 8, 105-123.

Mutsotso, B.M., Chirchir, J.K., 2005. The socio-economic aspects of sustainable agriculture and conservation of agrobiodiversity in Embu and Taita districts, Kenya. In: Global Conference on Conservation and Management of below Ground Biodiversity in Manaus, Brazil.

Nomura, C.S., da Silva, C.S., Oliveira, P.V., 2008. Solid sampling graphite furnace atomic absortion spectroscopy: a review. Quim. Nova 31, 104-113.

Olson, J.M., 2004. Multi-scale Analysis of Land Use and Management Change on the Eastern Slopes of Mt. Kenya the Land Use Change. Impacts and Dynamics Project (LUCID) Working Paper Nr. 20.

Ontl, T.A., Schulte, L.A., 2012. Soil carbon storage. Nat. Educ. Knowl. 3, 35.

Segnini, A., Posadas, A., Quiroz, R., Milori, D.M.B.P., Saab, S.C., Vaz, C.M.P., MartinNeto, L., 2010. Spectroscopic assessment of soil organic matter in wetlands from the high Andes. Soil Sci. Soc. Am. J. 74, 2246-2253.

Segnini, A., Posadas, A., Quiroz, R., Milori, D.M.B.P., Vaz, C.M.P., Martin-Neto, L., 2011. Comparative assessment of soil carbon stocks and stability in different agro-ecologies in southern Peru. J. Soil Water Conserv. 66, 213-220.

Segnini, A., Carvalho, J.L.N., Bolonhezi, D., Milori, D.M.B.P., Silva, W.T.L., Simões, M.L., Cantarella, H., Maria, I. de, Martin-Neto, L., 2013. Carbon stock and humification index of organic matter affected by sugarcane straw and soil management. Sci. Agric 70, 321-326.

Segnini, A., Xavier, A.A.P., Otaviani-Júnior, P.L., Oliveira, P.P.A., Pedroso, A.F., Praes, M.F.F.M., Rodrigues, P.H.M., Milori, D.M.B.P., 2019. Soil carbon stock and humification in pastures under different levels of intensification in Brazil. Sci. Agric. 76, 33-40.

Shepherd, K.D., Walsh, M.G., 2007. Infrared spectroscopy - enabling an evidence - based diagnostic surveillance approach to agricultural and environmental management in developing countries. Near Infrared Spectrosc. 15, 1-19.

Stenberg, B., Rossel, R.A.V., Mouazen, A.M., Wetterlind, J., 2010. Visible and near infrared spectroscopy in soil science. In: Sparks, D.L. (Ed.), Advances in Agronomy. Academic Press, Burlington, pp. 163-215.

Thangata, P.H., Hildebrand, P.E., 2012. Carbon stock and sequestration potential of agroforestry systems in smallholder agroecosystems of sub-Saharan Africa: mechanisms for 'reducing emissions from deforestation and forest degradation' (REDD +). Agric. Ecosyst. Environ. 158, 172-183.

Twongyirwe, R., Sheil, D., Majaliwa, J.G.M., Ebanyat, P., Tenywa, M.M., van Heist, M., Kumar, L., 2013. Variability of Soil Organic Carbon stocks under different land uses: a study in an afro-montane landscape in southwestern Uganda. Geoderma 193-194, 282-289.

UNFPA - United Nations Population Fund, 2007. State of World Population 2007: Unleashing the Potential of Urban Growth'. United Nations Population Fund, Geneva.

Veldkamp, A., Visser, P.W., 1992. Erosion surfaces in the Chuka-South area, Central Kenya. Z. Geomorphol. 84, 147-158.

Veldkamp, E., 1994. Organic-carbon turnover in 3 tropical soils under pasture after deforestation. Soil Sci. Soc. Am. J. 58, 175-180.

Vendrame, P.R.S., Marchão, R.L., Brunet, D., Becquer, T., 2012. The potential of NIR spectroscopy to predict soil texture and mineralogy in Cerrado Latosols. Eur. J. Soil Sci. 63, 743-775.

Walter, K., Don, A., Tiemeyer, B., Freibauer, A., 2016. Determining soil bulk density for carbon stock calculations: a systematic method comparison. Soil Sci. Soc. Am. J. 80, 579-591. 